\title{
CONTINUTUL ELEMENTELOR BIOGENE ÎN APELE RÂULUI BÂC ÎN PRIMĂVARĂ ANULUI 2018
}

\author{
Borodin Natalia \\ Institutul de Zoologie, or. Chișinău, Republica Moldova, \\ natalia_borodin@mail.ru \\ https://doi.org/10.53937/9789975315975.71
}

\begin{abstract}
The paper presents the research results on the content and spatial dynamics of biogenic elements (ammonium ions, nitrite ions, nitrate ions, mineral phosphorous) in the water of the Bâc river. The aim of the research was to determine the water quality of the Bâc river, in order to highlight the extent of the impact of anthropic factors on the river and to reveal the impact of the Bâc river on the state of the Dniester river. The water of the Bâc river, downstream of Calarasi, Straseni and Chisinau, is highly polluted with ammonium, nitrites, mineral phosphorus, which corresponded to the IV-V class of water quality - polluted and heavily polluted. The results of the research confirm the high degree of pollution with biogenic elements causing the changes of water quality in the Dniester river.
\end{abstract}

Key words: Bâc river, ammonium, nitrite and nitrate ions, water quality

\section{INTRODUCERE}

Râul Bâc este unul dintre afluenții de dreapta ai fluviului Nistru, care izvorăște și curge integral pe teritoriul Republicii Moldova. Bâcul își ia începutul lângă satul Temeleuți (raionul Călărași), în Codri din partea Centrală a Moldovei și se varsă în fluviul Nistru lângă satul Gura-Bâcului (raionul Anenii-Noi) [2]. Lungimea râului este de $155 \mathrm{~km}$, bazinul de recepție - de $2150 \mathrm{~km}^{2}$, debitul de apă - 2,3 m³/s [11]. Pe cursul mijlociu al râului Bâc, la nord de orașul Chișinău, se află lacul de acumulare Ghidighici. De la izvor și până la gura de vărsare, râul Bâc este alimentat prin afluenții săi Bucovățt, Ișnovăț și Calintir, precum și apele multor râulețe mici fără nume, pâraie și izvoare. Bazinul râului Bâc traversează partea centrală a Republicii Moldova, parcurgând teritoriile raioanelor Călărași, Strășeni, mun. Chișinău, Anenii-Noi, cu o populație de cca $1 \mathrm{mln}$. de locuitori (97 
de localități) cu suprafața terenurilor de 194.494 ha [4]. Influența negativă a factorului antropic asupra stării și calității apei râului Bâc, manifestate prin captarea izvoarelor, deversarea apelor tratate insuficient, aratul văilor practic până la albie ș.a., a condus la înrăutățirea acesteia, precum și la degradarea râului în întregime. La ora actuală, cursul râului Bâc este înnămolit, acoperit cu vegetație, pe alocuri secat.

Fiind unul dintre principalii afluenți ai fluviului Nistru și colector al apelor reziduale ale mun. Chișinău, râul Bâc modifică în mod direct componența chimică și calitatea apei în sectorul inferior al acestuia. Cercetările efectuate timp de mai mulți ani confirmă gradul înalt de poluare a râului Bâc, el având un conținut sporit de elemente biogene, substanțe organice dizolvate, regim insuficient de oxigen dizolvat $[1,9,10]$.

Un interes științific deosebit prezintă nivelul de poluare a apei cu elemente biogene în zona de confluență cu fluviul Nistru.

\section{MATERIALE ȘI METODE}

Cercetările au fost realizate în perioada de primăvară (luna mai) a anului 2018. Probele hidrochimice din râul Bâc au fost colectate în 7 puncte reprezentative pe cursul apei: or. Călărași (amonte, aval), or. Strășeni (amonte, aval), or. Chișinău (amonte, aval), s. Gura-Bâcului (zona de confluență). Din fl. Nistru au fost colectate probe în amonte și aval de revărsarea apelor Bâcului. Colectarea probelor de apă și analiza lor chimică a fost efectuată prin metode ISO [3; 6-8]. Punctele de colectare au fost selectate în modul în care s-ar putea evidenția amploarea acțiunii factorului antropic, provocând poluarea râului Bâc cu apele provenite din activitățile economice și comunale ale localităților situate pe cursul apei. Determinarea valorii pH a fost efectuată în teren, în momentul colectării probelor, cu ajutorul pH-metrului portabil Consort C5030. În condiții de laborator a fost determinat conținutul ionilor de amoniu $\left(\mathrm{N}-\mathrm{NH}_{4}{ }^{+}\right)$, nitriților $\left(\mathrm{N}-\mathrm{NO}_{2}{ }^{-}\right.$), nitraților $\left(\mathrm{N}-\mathrm{NO}_{3}{ }^{-}\right.$) și fosforului mineral (Pmin), utilizând spectrofotometrul Specord 210 AnalyticJena cu set de software. Evaluarea calității apei râului Bâc a fost efectuată conform Regulamentului cu privirea la cerințele de calitate a mediului pentru apele de suprafață, aprobat prin HG nr. 890 din 22.11.2013 [5]. 


\section{REZULTATE ȘI DISCUȚII}

Rezultatele investigațiilor au demonstrat că valorile $\mathrm{pH}$-ului au variat în limita de la 8,17 până la 9,97, astfel apele sunt bazice, iar temperatura apei a constituit $13,6-19,8^{\circ} \mathrm{C}$ ce este în concordanță cu sezonul colectării materialului.

Compușii azotului. lonii de amoniu în canțități mici întotdeauna există în apele de suprafață ca rezultat al proceselor metabolice ale hidrobionților, însă cantitățile mari ale acestor cationi reprezintă un indicator al poluării ecosistemelor acvatice. Pe cursul râului Bâc, diapazonul conţinutului ionilor de amoniu este extrem de mare în aval de orașele Călărași (stația 2), Chișinău (stația 6) și la st. Gura-Bâcului, sporind de câteva zeci de ori comparativ cu conținutul lor din zona de amonte a acestor localități (Fig.1). Sporirea conținutului ionilor de amoniu la ieșirea din aceste localități indică în mod direct o poluare antropică cu compuși organici. Cel mai mare conținut al ionilor de amoniu a fost înregistrat în aval de orașul Chișinău, având valoarea de 52,5 mgN/l. La stația Gura-Bâcului, apa râului are un conținut al ionilor de amoniu de $47,5 \mathrm{mgN} / \mathrm{l}$, ceea ce este de 200 de ori mai mult comparativ cu conținutul determinat în apa nistreană din amontele gurii de vărsare a Bâcului. Astfel, apele râului Bâc sporesc conţinutul ionilor de amoniu în fluviul Nistru de 5 ori (avalul confluenței), provocând degradarea calității apei fl. Nistru - de la clasa I de calitate la clasa IV.

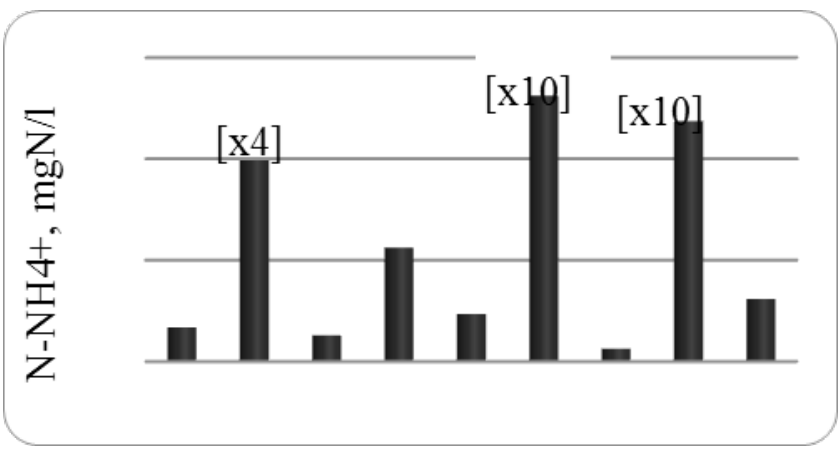

Fig. 1. Conţinutului ionilor de amoniu $\left(\mathrm{N}_{-} \mathrm{NH}_{4}^{+}\right)$în apele r. Bâc: 1 - Călăraşi amonte, 2 - Călăraşi aval, 3- Străşeni amonte, 4 - Străşeni aval, 5 Chişinău amonte, 6 - Chişinău aval, 7 - fl. Nistru amonte de r. Bâc, 8r. Bâc, până la revărsare, 9 - fl. Nistru, aval de revărsarea r. Bâc, mgN/l. 
Dinamica spațială a ionilor nitrit indică un conținut extrem de ridicat în aval de orașele Strășeni $(0,4$ mgN/l), Chișinău (0,25 mgN/I) și Gura-Bâcului $(0,19 \mathrm{mgN} / \mathrm{l})$ (Fig. 2).

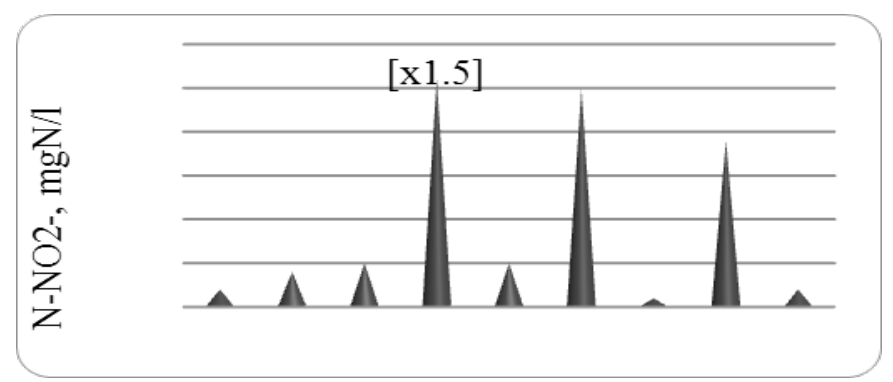

Fig. 2. Conţinutului ionilor nitrit (N-NO2-) în apele r. Bâc: 1 - Călăraşi amonte, 2 - Călăraşi aval, 3 - Străşeni amonte, 4 - Străşeni aval, 5 - Chişinău amonte, 6 - Chişinău aval, 7 - fl. Nistru amonte de r. Bâc, 8 - r. Bâc, până la revărsare, 9 - fl. Nistru, aval de revărsarea r. Bâc, mgN/l.

Conţinutul nitraţilor în apa râului Bâc nu depășește concentraţia de 2 $\mathrm{mgN} / \mathrm{l}$, ceea ce corespunde clasei II de calitate. La toate stațiile de colectare, cu excepția stației Strășeni amonte, a fost înregistrat un conţinut sporit de ioni de amoniu, care a prevalat asupra conţinutului de nitraţi, acest fenomen fiind caracteristic pentru ecosistemele acvatice poluate, cu deficit de oxigen, în deosebi, în zonele revarsării apelor reziduale menagere (Fig.3). În raza orașelor Călărași, Chișinău și la Gura-Bâcului conţinutul ionilor de amoniu alcătuiește peste $90 \%$ din conţinutul de azot mineral (Fig.3).

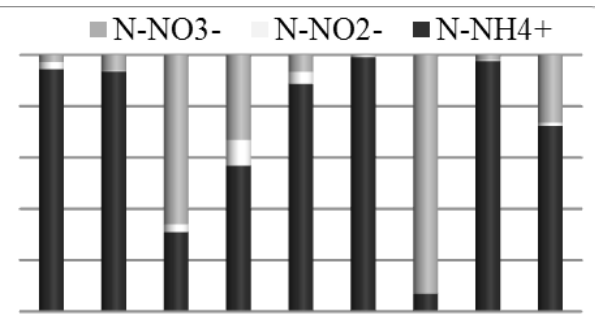

Fig. 3. Coraportul formelor minerale de azot în r. Bâc: 1 - Călăraşi amonte, 2 - Călăraşi aval, 3 - Străşeni amonte, 4 - Străşeni aval, 5 - Chişinău amonte, 6 - Chişinău aval, 7 - fl. Nistru amonte de r. Bâc, 8 - r. Bâc, până la revărsare, 9 - fl. Nistru, aval de revărsarea r. Bâc, mgN/I 
În perioada de cercetare la toate stațiile de colectare de pe r. Bâc a fost înregistrat un conținut sporit de fosfor mineral, care a variat de la 0,07 mgP/l (Chișinău, amonte) până la 4 mgP/l la revărsare în fl.Nistru (Gura-Bâcului) (Fig. 4). Aceste concentraţii sporite provin în cea mai mare parte, probabil, din deversările apelor menajere. În apele fl. Nistru, sub influența apelor $r$. Bâc, concentrația fosforului mineral sporește de la 0.003 mgP/l (în amontele confluenței) până la 0,12 mgP/l (în avalul confluenței), atribuind apei fl. Nistru clasa III de calitate (Fig. 4).

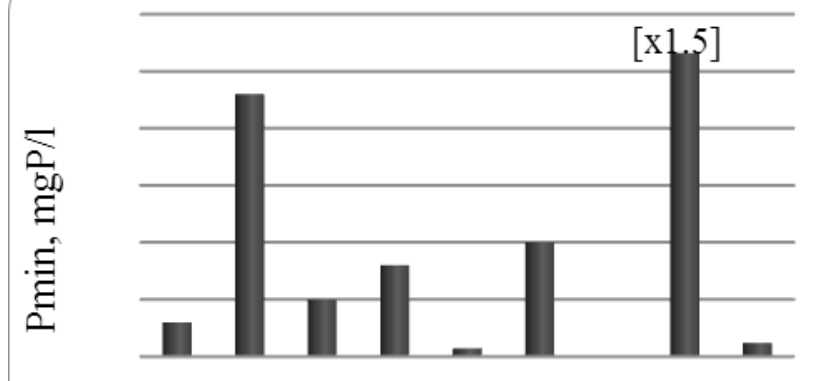

Fig. 4. Dinamica fosforului mineral în apele r. Bâc: 1 - Călăraşi amonte, 2 - Călăraşi aval, 3 - Străşeni amonte, 4 - Străşeni aval, 5 - Chişinău amonte, 6 - Chişinău aval, 7 - fl. Nistru amonte de r. Bâc, 8 - r. Bâc, până la revărsare, 9 - fl. Nistru, aval de revărsarea r. Bâc, mgN/l

Calitatea apei r. Bâc. Conţinutul elementelor biogene înregistrate în apa râului Bâc provine, în cea mai mare parte, din deversările apelor uzate. Aceste concentraţii nu permit funcţionarea ecosistemului acvatic și devin toxice pentru creșterea și dezvoltarea hidrobionţilor. Rezultatele analizelor hidrochimice efectuate au permis determinarea claselor de calitate a apei (Tab.1).

Tabelul 1. Clasa de calitate a apei r. Bâc

\begin{tabular}{|l|l|l|l|}
\hline Stația & $\mathbf{N}^{-N_{H}{ }^{+}}$ & $\mathbf{N}-\mathbf{N O}_{\mathbf{2}}{ }^{-}$ & $\mathbf{P}_{\text {min }}$ \\
\hline 1 - Călărași amonte & III & II & IV \\
\hline 2 - Călărași aval & $\mathrm{V}$ & II & V \\
\hline
\end{tabular}




\begin{tabular}{|l|l|l|l|}
\hline 3 - Strășeni amonte & III & II & IV \\
\hline 4- Strășeni aval & IV & V & V \\
\hline 5 - Chișinău amonte & IV & II & II \\
\hline 6- Chișinău aval & V & IV & V \\
\hline 7 - fl. Nistru amonte de r. Bâc & III & I & I \\
\hline 8- r. Bâc, până la revărsare & V & IV & V \\
\hline 9 - fl. Nistru, aval de revărsarea r. Bâc & IV & II & III \\
\hline
\end{tabular}

S-a dovedit că apa râului Bâc este puternic poluată, atribuindu-se în cea mai mare parte claselor IV-V de calitate, ceea ce corespunde caracteristicii de poluată și puternic- poluată.

\section{CONCLUZII}

Dinamica elementelor biogene în apele râului Bâc este influențată de deversările apelor uzate ale orașele Călărași, Strășeni și mun.Chișinău în aval de aceste localități apele r. Bâc sunt atribuite claselor IV și V de calitate, ceea ce corespunde categoriei de apă poluată și puternic-poluată. Conținutul elementelor biogene indică diminuarea proceselor de autoepurare a apei râului Bâc, ce oferă condiții nesatisfăcătoare pentru creșterea și dezvoltarea hidrobionților. Revărsarea râului Bâc provoacă poluarea apelor fluviului Nistru cu compuși de azot și fosfor mineral.

Mulțumire. Rezultatele investigațiilor au fost obținute în cadrul proiectului pentru tineri cercetători 18.80012.50.21A "Evaluarea structurii hidrobiocenozelor și calităţii apei râurilor Răut și Bâc" și proiectului instituțional 15.817.02.27A AQUASYS.

\section{BIBLIOGRAFIE}

1. Duca Gh. și al. Impactul afluenților din dreapta asupra calității apelor fluviului Nistru în perioada de primăvară a anului 2009. În: Studia Universitatis Moldaviae, Revistă Științifică a Universității de Stat din Moldova, nr.1 (31), 2010, p. 146-154.

2. Eremia A. Hidronimia bazinului hidrografic al Nistrului. În: Akademos, Nr. 
3, 2017, pag. 132-138.

3. Monitoringul calităţii apei și evaluarea stării ecologice a ecosistemelor acvatice. Îndrumar metodic. Chișinău, 2015. 84 p.

4. Raport-sinteză privind situația ecologică în bazinul rîului Bîc. Elaborat de Mihai Mustea, Centrul Național de Mediu, 17 p.

5. Regulament cu privire la cerinţele de calitate pentru apele de suprafaţă. Aprobat prin Hotărîrea Guvernului Nr. 890 din 12.11.2013. Publicat: 22.11.2013, Monitorul Oficial Nr. 262-267, art. Nr.1006, 2013, p. 32 - 39.

6. SM SR EN ISO 6878:2011. Calitatea apei. Determinarea fosforului. Metoda spectrophotometrică cu molibdat de amoniu, 9 p.

7. SM SR ISO 5667-6:2011. Calitatea apei. Prelevare. Partea 6: Ghid pentru prelevările efectuate în râuri și cursuri de apă. Chișinău: INSM, 2011.23 p.

8. SM SR ISO 7890-3:2006. Calitatea apei. Determinarea conţinutului de azotaţi, 9 p.

9. Бойченко Н.И. Аинамика содержания биогенных элементов и органического вещества в реке Анестр и его притоках - Стрый, Реут, Бык. В: Вода и заоровье, ОАесса, 2000, с. 83-85.

10. Горячева, Н. В. Гилрохимия малых рек Республики Молдова: монография/Н. В. Горячева, Г.Г. Аука; МолА. гос. ун-т, фак. химии и химической технологии, кафеАра индустриальной и экологической химии. - Chișinău: CE USM, 2004. 288 с.

11. Горячева Н. и Ар. Биогенный вынос в Анестр с территорий малых водосборов. В: Studia Universitatis Moldaviae, Revistă Științifică a Universității de Stat din Moldova, nr.1 (61), 2013, p. 124-130. 